\title{
LIFE EXPECTANCY FOLLOWING SPINAL CORD INJURY: A TEN-YEARS SURVEY IN THE RHÔNE-ALPES REGION, FRANCE, 1969-1980
}

\author{
By P. Minaire, P. Demolin, J. Bourret, R. Girard, E. Berard, C. \\ Deidier, M. EysSeTte and A. Biron \\ Université de Sainte Etienne, 42023 Saint Etienne, France, Hôpital Henry Gabrielle, \\ 69230 Saint Genis Laval, France
}

Summary. A ten years survey of 848 patients having sustained traumatic spinal cord injury between I 969 and I 979 was conducted in the Rhône-Alpes Region, France. All patients had been referred to the spinal cord injury unit, Hôpital Henry Gabrielle. 48 deaths were recorded: 36 patients admitted early to the Unit, and 12 patients injured before I 969 but followed-up in the Unit. The deceased patients were older and more frequently male and tetraplegic than the rest of the group. In 75 per cent of the deceased patients, the survival time was less than $\mathrm{I} / 5$ of the theoretical life expectancy. In 59 per cent, it was less than $\mathrm{I} / \mathrm{IO}$. Twenty tetraplegics died of respiratory complications. Three patients committed suicide, the rest died of urinary complications. The results appear to determine a secondary period with high mortality rate, after the initial high mortality of these patients. About one year post-injury, the life expectancy in our series appears to tend towards the values observed in the French population.

Key words: Traumatic Paraplegia; Life Expectancy.

\section{Introduction}

HôpItal Henry Gabrielle was founded in November 1969, when the Spinal Cord Injury Unit there was also opened. From November I969 to December I979, I,234 patients with spinal cord disease and injury were admitted. 386 spinal cord lesions ( $3 \mathrm{I} \cdot 28$ per cent) were non-traumatic, 848 $(68.72$ per cent) were of traumatic origin and 80 per cent of these traumatic lesions had occurred less than 6 months before admission. This has been the case especially during the past five years.

The mean age for the traumatic patients was 32.7 years for males, and 34.3 years for females. Most occurred between 20 and 25 years of age. Eighty per cent of those with trauma were between I 5 and 55 years of age; $8 \mathrm{I} \cdot 6$ per cent were born in France.

It seemed interesting to us to study the survival rate of these patients, after the spinal centre had been active for Io years. During these ro years, almost all spinal cord injuries in the Rhône-Alpes Region (population of 5 millions) and of some adjacent areas, were referred to Hôpital Henry Gabrielle. It was also important to study the rehospitalisation rate, and the post-hospital discharge cost to enable us to plan the next ro years of activity of the institution.

Read at the Scientific Meeting of the International Medical Society of Paraplegia at Stoke Mandeville in July I98I. 


\section{Material and Methods}

The life expectancy survey concerned the whole sample of 848 spinal cord injured patients. This sample was not homogeneous, as some patients were injured several years before 1969, the most recent in 1979. But we were able to analyse each spinal cord injury patient who died.

The survey took place between January and December i 980 . We sent a simple questionnaire to the town-hall of the place of birth of each patient. The questionnaire was addressed directly to the mayor, with a short explanation about the aims of the survey. The name of the place of birth was obtained through the computer service, University Hospitals of Lyon. The administrative data are routinely immediately computerised on admission, and the place of birth is always included in these data.

We obtained a prompt accurate reply for all patients born in France, where deaths are always recorded in the books at the patient's birthplace, and in a few foreign countries. We obtained no information for 65 patients, all foreign-born, mainly in North Africa. Finally the survey included 783 out 848 patients $(92.33$ per cent) admitted to the Spinal Cord Injury Unit between I.I I.69 and 3I.I2.79.

\section{Results}

Among the 783 patients included in the study, 48 deaths were reported by the town clerks (6.13 per cent). Thirty six cases belonged to the group of patients admitted earlier than 6 months after the injury. Twelve patients had been injured more than 6 months before admission, and I I of these I 2 had been injured more than 2 years before their first admission to the Unit. They were patients living in the Region, but transferred initially to other S.C.I. units before our hospital was opened. The percentage of late initial admissions was I6 per cent of the total S.C.I. population (I 26 out of 783) and 25 per cent ( 12 out of 48 ) of the deceased group.

The male/female ratio was 3.50 for the whole group, 4.33 for the deceased ( $p>0.05$ non significant).

The percentage of tetraplegics in both group is given in Table I:

TABLE I

\begin{tabular}{lll}
\hline & Deceased & Total S.C.I. \\
\hline Tetraplegics & 2I $=44 \%$ & $220=30 \%$ \\
Paraplegics & $27=56 \%$ & $510=70 \%$ \\
\hline
\end{tabular}

The mean age for the deceased was 43.6 years, compared to 32.5 for the whole group of S.C.I. patients, with identical ranges: I 8 to 76 and 6 to $9 \mathrm{I}$ years.

The deceased patients had sustained a spinal cord injury from aetiologies similar to the rest of the group (Table II).

The cause of death was due to a respiratory complication in 20 tetraplegic patients, and urinary complication in ro cases. The cause of death was not known in 17 patients. Three deaths were due to suicide and one other was possibly from suicide. These three young patients had been 
TABLE II

Aetiology of the spinal cord injury

\begin{tabular}{lrrrc}
\hline & \multicolumn{2}{c}{ Deceased } & \multicolumn{2}{c}{ Total S.C.I. Patients } \\
\hline Fall & I2 & $25 \%$ & 209 & $24 \cdot 7 \%$ \\
Auto & I6 & $58 \%$ & 272 & $46 \%$ \\
2-wheelers & I2 & & I I 7 & \\
Direct blow & 2 & & 50 & \\
Diving & I & & 25 & \\
Suicide & 3 & $6 \%$ & 45 & $5 \cdot 3 \%$ \\
Gunshot & 0 & & 2 I & \\
Sport & 0 & & 26 & \\
\hline
\end{tabular}

injured in car accidents. Two of the suicides resulted from taking drugs, and the third from a car accident. Three other patients became paraplegic from attempted suicide; they died of complications arising within 6 months post-injury.

The place of death was known for 47 patients: 18 died in the S.C.I. Unit, 23 in another hospital, six at home.

If we exclude patients admitted to the Unit more than 6 months post-injury, only 25 per cent ( 9 out of 36 ) died more than one year after their accident $(\mathrm{p}<0.00 \mathrm{I})$. This meant that late death occurred in only I'I per cent of all S.C.I. patients (9 out of 783). When the lateadmission patients are included, a total of 20 out of 48 died more than one year post-injury.

These findings prompted us to calculate the ratio $\mathrm{X}$ between the theoretical life expectancy for matching age and sex $(\mathrm{EV})$ and the observed survival (DS), according to the equation:

$$
\mathrm{X}=\frac{\mathrm{EV}-\mathrm{DS}}{\mathrm{EV}}
$$

$\mathrm{EV}=$ Theoretical Life expectancy for matching age and sex; DS = Observed Survival.

$\overline{\mathrm{X}}=0.8 \mathrm{In}=44$

$\mathrm{X}>0.8 \mathrm{n}=34$

$\mathrm{X}<0 \quad \mathrm{n}=\mathbf{2}$

$0<\mathrm{X}<0.8 \mathrm{n}=8$

In 75 per cent of cases, survival was less than $\mathrm{I} / 5$ of the theoretical life expectancy.

$X>0.9 n=26$

In 59 per cent of cases, survival was less than I/IO of the theoretical life expectancy.

EV was given by De Vivo's tables (I980). 


\section{Discussion}

Among 783 patients with spinal cord injury admitted at the Henry Gabrielle Hospital S.C.I. Unit between 1969 and 1979, and for whom information was obtained from local municipalities, only 48 died. They were mostly tetraplegic patients, older than the other S.C.I. patients, and with a greater male/female ratio. Death usually occurred before one year post-injury: 59 per cent and 75 per cent of the patients lived only respectively I/IO and I/ 5 of their theoretical life expectancy.

The short follow-up of our paraplegic population may explain the very low mortality rate. We believe that our Unit had the opportunity to benefit from the experiences accumulated over the years by senior centres such as Stoke Mandeville, Heidelberg, Fontainebleau, Garches, and Hôpital Brugmann, where early good care was available. It is interesting to note that 25 per cent of the deaths concerned patients not initially included in our rehabilitation programme.

It must be pointed out that this survey only included patients admitted to the Unit. This, added to the small number of recorded deaths, explains why we were not able to construct a survival curve like that of Kraus (I 979). His study showed an impressive initial mortality rate (48.3 per cent). Ours is centred on the 'secondary' rehabilitative period. We confirm the high initial mortality rate prior to one year post-injury ( 75 per cent of all the recorded deaths). After this statistical threshold has been reached, the risk is almost the same as for the rest of the population. For the spinal cord injury patient who has survived the first 24 hours, the unstable and at riskperiod lasts between 6 months and I year post-injury.

If we examine the curves presented by Kraus (1979) we note that from 5.5 weeks (mean delay of admission to Henry Gabrielle S.C.I. Unit) to 5 years post-injury, the supplementary loss of life is about 5 per cent. This figure is close to ours for this 'secondary' period: 4.5 per cent for the early admission patient, 6. I3 per cent for all the deceased patients. This confirms the interest of determining three periods in the mortality and survival rate studies in S.C.I. patients:

I. An initial period, up to seven days, with an extremely high mortality rate of almost 50 per cent (Kraus, I 979);

2. A secondary period of about 6 to 12 months, with another loss of 5 per cent.

3. A third period with 'normal' mortality and survival rates.

Unfortunately we only have limited information about the causes of death of our patients. Twenty paraplegics died of acute respiratory insufficiency, of ten from bronchitis and airway obstruction. In some patients there was evidence of incomplete or late treatment, because the patient, the family, and the physician did not appreciate the importance of and the seriousness of common respiratory symptoms in tetraplegics. This is particularly true for older patients (Geisler, 1977). The mean age of our deceased tetraplegics is $48 \cdot 5$ years, $40 \cdot 6$ for the others.

Although our follow-up is short, renal insufficiency appears to be the main cause of death in paraplegic patients. Five patients had already undergone a Bricker's procedure.

The higher male/female ratio in our deceased patients may be explained in different ways. Males are involved in more severe initial trauma, 
especially occupational trauma. Serious urinary complications occur more often in the male than in the female urinary tract.

Tetraplegic patients are obviously more at risk and their higher mortality rate is not surprising and accords with other reports (Kraus, I979; Geisler and Jousse, 1977). But for this group, also the survival rate is stable after the secondary period.

Finally, it must be noted that two patients showed a higher survival time than their theoretical life expectancy. This might occur more frequently in the future, and confirms the necessity for a young S.C.I. unit to provide the facilities for an expanding follow-up activity.

In conclusion, in a recent unit, utilising the experiences of longer established centres, there is an extremely high survival rate one year postinjury. Such figures are of values for National Health planners and for private car insurers, and have already been taken into account. This is also encouraging for the pioneers as well as to the newcomers in the field of paraplegia. It is fashionable, especially in France, to comment on the Cost-Effectiveness ratio of these high survival rates. We will rather insist on the necessity of providing them with the best quality of life.

\section{RÉSUMÉ}

Une étude de 848 blessés médullaires accidentés entre I969 et I979 a éte menée dans la région rhône-Alpes en France. Tous ces Blessés avaient été adressés à l'unité de soins aux Blessés médullaires de l'hopital Henry Gabrielle. 48 décès furent enregistrés: 36 concernaient des patients admis peu de temps après l'accident, I 2 des patients blessés avant 1969, mais suivis par le service. Les sujets décédés étaient plus âgés, plutôt de sexe masculin, et plus souvent tétraplégiques que le reste du groupe. Dans $75 \%$ des cas de décès, la survie était inférieure à $\mathrm{I} / 5$ de la survie théorique; dans $59 \%$ des cas, elle était inférieure à $\mathrm{I} / \mathrm{I} O$. Vingt tétraplégiques sont décédés de complications respiratoires. Trois patients se suicidèrent, le reste décédant de complications urinaires. Les résultats semblent déterminer après la mortalité initiale élevée déjà connue, une période secondaire de moralité encore supérieure à la normale. Environ un an après le traumatisme, l'espérance de vie dans notre série semble rejoindre les valeurs normales de la population française.

\section{ZUSAMMENFASSUNG}

Eine Untersuchung über 848 Markverletzungen infolge von Unfällen wurde zwischen 1969 und 1979 im Rhône-Alpen-Gebiet in Frankreich durchgefürhrt. Sämtliche Verletzte wurden in die Abteilung für Markverletzungen des Krankenhauses Henry Gabrielle eingewiesen. Es wurden 48 Todesfälle verzeichnet: 36 davon betrafen patienten, die kurze Zeit nach dem Unfall aufgenommen wurden, I2 vor 1969 verletzte, von der Abteilung weiterbehandelte Patienten. Bei den Todesfällen handelte es sich um ältere, vorwiegend männliche Patienten, die zahlreichere Fälle von Tetraplegie darstellten als der Rest der Gruppe. In $75^{\circ}$ o der Todesfälle lag die Überlebensquote bei $1 / 5$ der theoretischen Überlebensquote; in $59 \%$ der Fälle lag sie bei unter I/IO. Bei zwanzig Teraplegiepatienten war die Todesursache: respiratorische Komplikationen. Drei Patienten begingen Selbstmord, die übrigen verstarben an Harnkomplikationen. Die Ergebnisse scheinen nach der schon bekannten hohen anfänglichen Sterblichkeit eine noch über der Normalquote liegende sekundäre Sterblichkeitsperiode aufzuzeigen. Ungefähr ein Jahr nach der Verletzung läuft die Lebenserwartung unserer Gruppe anscheinend mit den Normalwerten für die französische Bevölkerung zusammen.

\section{REFERENCES}

De Vivo, M. J., Fine, P. R. (I980). The prevalence of spinal cord injuries: A reestimation based on the life tables. S.C.I. Digest, $\mathbf{I}$, Winter issue.

Geisler, W. O., Jousse, A. T. (1977). Survival in traumatic transerse myelitis. Paraplegia, 14, 262-275.

KRAUS, J. F. (1979). Survival with an acute spinal cord injury. f. of Chronic Dis., 32, 269-283. 